\title{
STRUKTUR UKURAN DAN HUBUNGAN PANJANG BERAT IKAN KURAU DI PULAU BENGKALIS
}

\section{Size Structure and Length Weight Relationship of Kurau Fish in Bengkalis Island}

\author{
Oleh: \\ Muhammad Natsir Kholis ${ }^{*}$, Ronny I Wahju², Mustaruddin², Jaliadi ${ }^{3}$ \\ ${ }^{1}$ Staf Pengajar Jurusan Pemanfaatan Sumberdaya Perikanan Fakultas Perikanan, Universitas \\ Muara Bungo-Jambi \\ ${ }^{2}$ Staf Pengajar Jurusan Pemanfaatan Sumberdaya Perikanan Fakultas Periknan dan Ilmu \\ Kelautan, Institut Pertanian Bogor-Jawa Barat \\ ${ }^{3}$ Fakultas Perikanan dan Ilmu Kelautan, Universitas Teuku Umar-Meulaboh-Aceh \\ *Korespondensi: kholis2336@gmail.com
}

\begin{abstract}
ABSTRAK
Pengelolaan perikanan kurau perlu memperhatikan aspek biologi untuk keberlanjutan usaha penangkapan, mengingat produksinya terus menurun dan tingginya harga ikan kurau dipasaran. Penelitian ini bertujuan untuk menganalisis sebaran struktur ukuran, persentase ikan layak tangkap serta hubungan panjang dan berat ikan kurau yang tertangkap oleh beberapa alat tangkap di perairan pulau Bengkalis. Pengumpulan data dilaksanakan pada bulan Juli-September 2016 di Pambang Pesisir Kabupaten Bengkalis Provinsi Riau dengan metode experimental fishing. Metode analisis yang digunakan yaitu hubungan panjang dan berat serta frekuensi sebaran panjang. Hasil analisis menunjukkan bahwa pola pertumbuhan ikan kurau bersifat allometrik negatif, dengan kisaran ukuran yang tertangkap pada alat tangkap jaring insang dominan berada pada 31,7-42,7 cm pada bulan Juli dan September serta kisaran 61,7-72,7 cm pada bulan Agustus. Sedangkan ukuran ikan kurau yang tertangkap pada rawai dan pancing dominan berada pada kisaran 31,7-42,7 $\mathrm{cm}$ pada bulan Juli dan September serta kisaran 36,7-47,7 cm pada bulan Agustus. Persentase ikan kurau layak tangkap pada jaring insang yaitu untuk jantan 100\% layak tangkap dan 72\% layak tangkap untuk betina. Sedangkan ikan kurau yang layak tangkap pada rawai dan pancing untuk jantan $90 \%$ dan $44 \%$ layak tangkap untuk betina.
\end{abstract}

Kata kunci: Hubungan panjang dan berat, ikan kurau, Pulau Bengkalis, ukuran layak tangkap.

\section{ABSTRACT}

Kurau fisheries management needs to consider the biological aspects of business sustainability fishing, given its production continues to decline and the high price of kurau fish in the market. The purpose of this study was to analyze the distribution of the size of the structure, the percentage of decent fish caught as well as the length and weight relationship of kurau fish caught by some fishing gear in the waters of the Bengkalis island. Data collection was carried out from July-September 2016 in the Coastal Pambang Bengkalis District Riau Province by using the experimental fishing method. The analytical method used is the length and weight relationship as well as the frequency distribution of the length. Results of research show that kurau fish the pattern of growth is allometric negative, size range were caught in the gill net dominant are at 31.7-42.7 cm in July and September as well as the range of 61.7-72.7 cm in August. While the size of kurau fish caught on mini longline and fishing line dominant in the range of 31.7-42.7 cm in July and September as well as the range of 36.7$47.7 \mathrm{~cm}$ in August. Decent caught percentage of kurau fish in gill nets is for 100\% caught male and 
72\% decent caught for females. While kurau fish decent caught on mini longline and fishing line for males $90 \%$ and $44 \%$ decent caught for females.

Keywords: Length and weight relationship, kurau fish, Bengkalis island, decent size caught.

\section{PENDAHULUAN}

Desa Pambang Pesisir terletak lebih kurang $45 \mathrm{~km}$ ke arah timur dari Ibu Kota Kecamatan (Selat Baru) dan 65 km dari Ibu Kabupaten Bengkalis, dengan luas wilayah lebih kurang 943,6 hektar dengan batas wilayah sebagai berikut: sebelah utara berbatasan dengan Desa Muntai dan Selat Malaka, sebelah timur berbatasan dengan Selat Malaka, sebelah Selatan berbatasan dengan Desa Pambang Baru dan sebelah barat berbatasan dengan desa Pambang Baru dan Desa Muntai.

Perkembangan usaha perikanan tangkap di Pambang Pesisir terutama ikan kurau telah memberikan kontribusi cukup besar terhadap peningkatan ekonomi masyarakat. Hal ini menyebabkan sumberdaya ikan kurau (Eleutheronema tetradactylum) di perairan Pambang Pesisir terus dieksploitasi secara besar-besaran oleh beragam alat tangkap. Rentan waktu 11 tahun terakhir produksi ikan kurau menunjukkan penurunan produksi yang tajam sebesar 70\%.

Kerentanan spesies ikan kurau terhadap tekanan penangkapan sangat berdampak terhadap hasil tangkapan nelayan, mengingat konsekuensi dari sifat biologis ikan kurau yang bersifat hermaphrodit protandouse, yaitu kemampuan mengubah organ kelamin seiring dengan perkembangan ukuran dan umur (Wijopriono et al., 2012) serta ikan kurau matang gonad pertama kali sebagai jantan kemudian berubah menjadi betina (Poepoe et al., 2003).

Tekanan penangkapan biasanya mengarah ke individu ukuran yang lebih besar dalam populasi sehingga betina terkena tekanan penangkapan yang lebih tinggi (Milton et al., 1998). Hal ini mempunyai dampak yang besar terhadap total produksi telur dari keseluruhan populasi, dengan demikian akan mengarah kepada recruitment overfishing dan spesies hermaphrodit protandouse yang akan paling banyak mati (Blaber et al., 1999).

Potensi maksimum lestari (MSY) ikan kurau di Kabupaten Bengkalis yaitu sebesar 2.345,60 ton/tahun dengan jumlah tangkapan optimum (JTB) yaitu sebesar 1.876,48 ton/tahun (Sari et al., 2009) dan upaya optimum sebesar 151,000 trip (Syaifuddin, 2008). Namun demikian Rengi (2015) menyatakan saat ini ikan kurau telah mengalami overfishing sebesar 33,42\% dari tingkat pemanfaatan optimal upayanya sebesar 141.949 ton/tahun, optimal biomass 15.321,34 ton dan optimal menangkap 4.407,72 ton.

Informasi mengenai biologi ikan kurau masih sangat terbatas, seperti hubungan panjang dan berat, kebiasaan makanan, tingkat kematangan gonad dan fekunditas (Asyari dan Herlan, 2013). Oleh karena itu penulis tertarik untuk melakukan penelitian tentang struktur ukuran, ikan layak tangkap serta hubungan panjang dan berat ikan kurau.

Tujuan penelitian ini yaitu untuk menganalisis sebaran struktur ukuran, persentase ikan layak tangkap serta hubungan panjang dan berat ikan kurau yang tertangkap oleh beberapa alat tangkap di perairan Pambang Pesisir Kabupaten Bengkalis Provinsi Riau. Implementasinya ke depan diharapkan informasi tentang biologi ikan kurau yang relevan dapat dijadikan sebagai acuan dalam upaya pengelolaan usaha penangkapan ikan kurau yang berkelanjutan.

\section{METODE PENELITIAN}

Penelitian ini dilaksanakan pada bulan Juli-September 2016. Fishing base pengumpulan data penelitian ini yaitu Desa Pambang Pesisir Kabupaten Bengkalis Provinsi Riau (Gambar 1). 


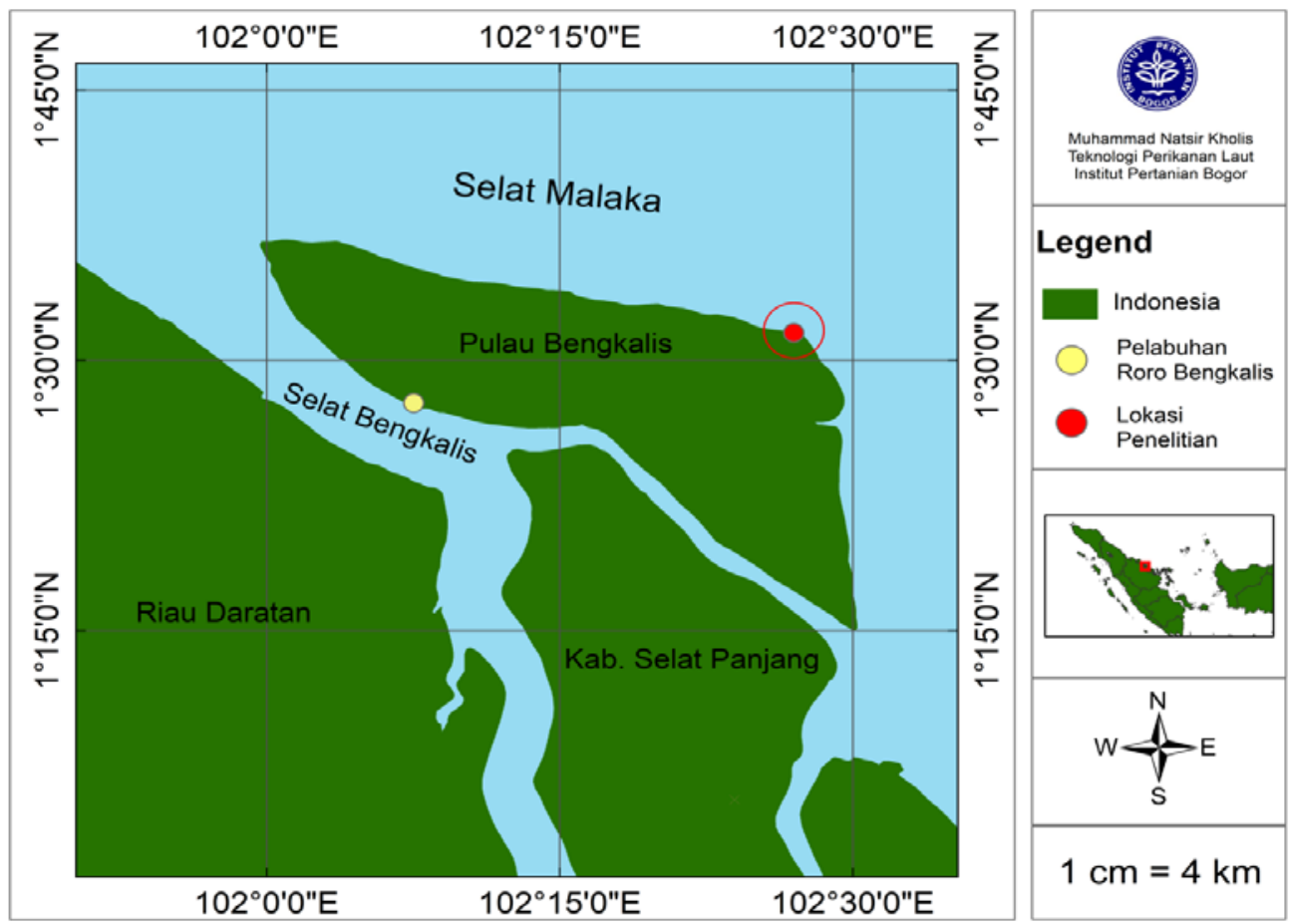

Gambar 1.Peta Lokasi Penelitian (Fishing Base)

Jenis data yang dikumpulkan pada penelitian ini yaitu data primer dan data sekunder.Data primer didapatkan dengan melakukan pengukuran langsung terhadap cagak fork length (FL) dan berat ikan kurau yang tertangkap oleh nelayan selama periode Bulan Juli-September 2016 di beberapa lokasi sampling. Beberapa Desa yang menjadi tempat pengambilan sampel ikan kurau yaitu: Pambang Pesisir, Teluk Pambang, Sungai Sei Kembung (Kembung Luar), Pambang Baru, Muntai, Selat Baru dan Prapat Tunggal (Meskom) (Gambar 2). Sedangkan data sekunder diperoleh dari tinjauan pustaka penelitian sebelumnya yang relevan terhadap penelitian terutama aspek biologi ikan kurau.

Alat yang yang digunakan dalam penelitian ini yaitu: meteran (rol), penggaris, nampan, coolbox, timbangan dan alat tulis. Sedangkan bahan yang digunakan yaitu: ikan kurau, es dan bahan pengawet. Analisis data dilakukan dengan beberapa cara, yaitu:

1. Analisis Ukuran Ikan Layak Tangkap

Analisis ini digunakan untuk melihat ukuran ikan kurau yang layak tangkap, berdasarkan nilai Lm (Length Maturity) ikan kurau menurut Patnaik (1969) yaitu $350 \mathrm{~mm}(35 \mathrm{~cm})$ untuk jantan dan $450 \mathrm{~mm}(45 \mathrm{~cm})$ untuk betina. Ukuran layak tangkap ikan kurau akan disajikan dalam bentuk persentase persen (\%) yang membandingkan antara ikan kurau yang layak tangkap dan tidak layak tangkap. Teknik pengukuran morfometrik ikan kurau dapat dilihat pada (Gambar 3).Menurut Wujdi et al. (2013), cara menghitung persentase dari ikan layak tangkap dan tidak layak tangkap adalah:

$$
\text { Persentase }(\%)=\frac{\text { jumlah ikan layak atau tidak layak tangkap }}{\text { jumlah sampel keseluruhan }}
$$




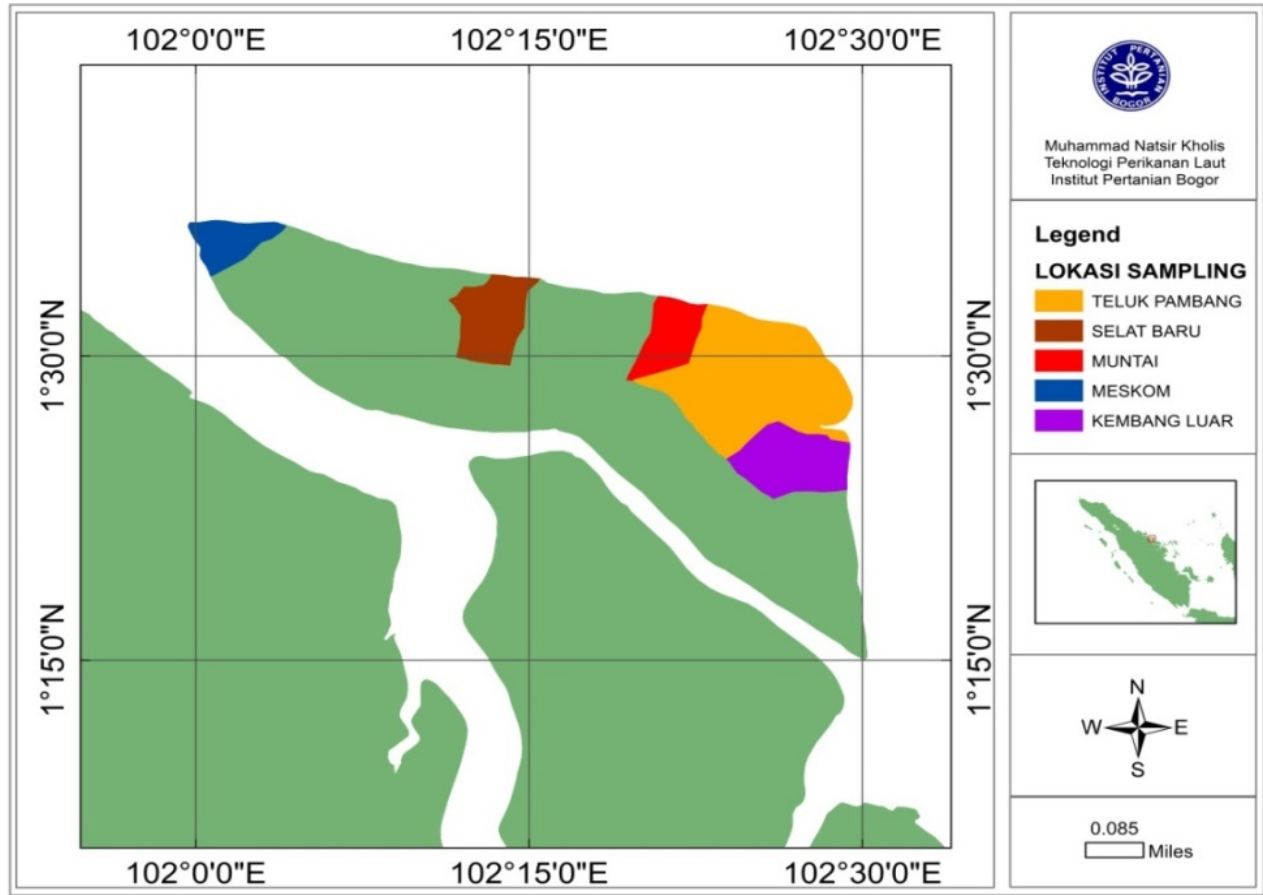

Gambar 2. Lokasi Sampling Pengambilan Sampel Ikan Kurau

2. Analisis Struktur Ukuran

Analisis ini digunakan untuk mengetahui frekuensi sebaran ikan kurau yang tertangkap selama periode Bulan Juli-September 2016. Rumus yang digunakan yaitu menggunakan persamaan (Walpole, 1995):

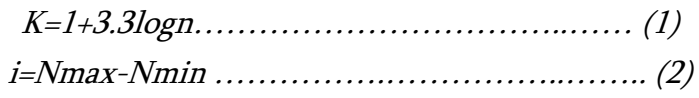

Keterangan:

$K=$ Jumlah kelas

$n=$ Jumlah data

$i=$ Selang kelas

$N \max =$ Nilai terbesar dan

$N$ main = Nilai terendah

3. Analisis Hubungan Panjang Berat

Untuk mencari hubungan antara panjang dan berat tubuh ikan digunakan persamaan sebagai berikut:

$$
\mathrm{W}=\mathrm{aLb} \text { (Effendie, 1997); (De Robert \& William, 2008). }
$$

Keterangan :

$\mathrm{W}=$ Berat tubuh ikan kurau (gram)

$\mathrm{L} \quad=$ Panjang ikan kurau $(\mathrm{mm})$

$\mathrm{a}$ dan $\mathrm{b}=$ Konstanta

Nilai b sebagai penduga hubungan antara panjang dan berat dengan kriteria:

Nilai $b=3$, ikan memiliki pola pertumbuhan isometric (pertambahan berat seimbang dengan pertambahan panjang). 
Nilai b> 3, ikan memiliki pola pertumbuhan allometrik positif (pertambahan berat lebih cepat dari pertambahan panjang).

Nilai $b<3$, ikan memiliki pola pertumbuhan allometrik negatif (pertambahan panjang lebih cepat dari pertambahan berat).

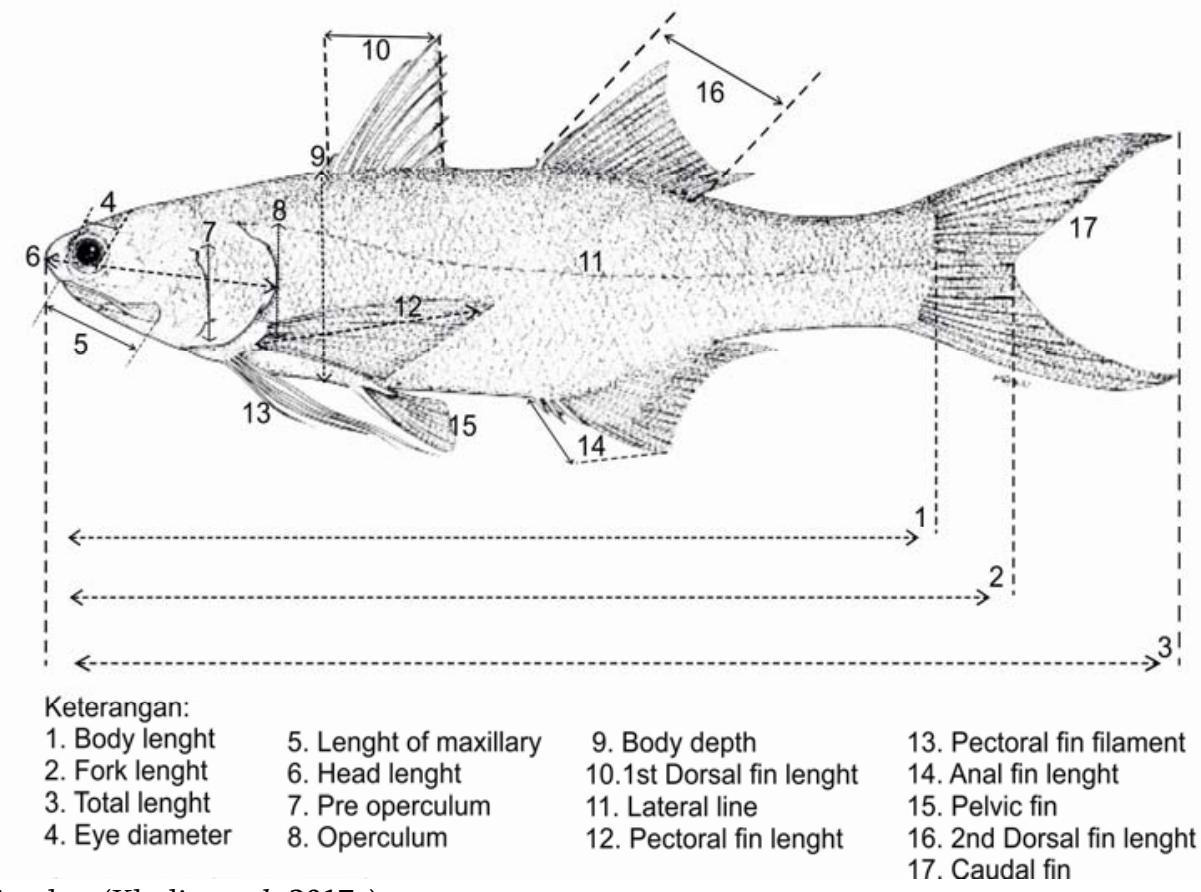

Sumber:(Kholis et al,. 2017a)

Gambar 3. Teknik Pengukuran Morfometrik Ikan Kurau

\section{HASIL DAN PEMBAHASAN}

\section{Identifikasi Ikan Kurau}

Ikan kurau merupakan ikan target utama buruan masyarakat nelayan Kabupaten Bengkalis. Ikan kurau ditangkap secara besar-besaran karena harga jual ikan ini yang tinggi dan memiliki nilai tambah selain dagingnya seperti lambung dan gelembung renang. Lambung dan gelembung renang ikan kurau yang dikeringkan memiliki harga jual cukup tinggi sekitar Rp.1.000.000/kg, lambung dan gelembung renang ikan kurau dipercaya mampu mengobati berbagai penyakit seperti asma, jantung, usus buntu dan gangguan kehamilan.

Ikan kurau hidup di perairan yang berlumpur, berpasir, tanah liat dan berbatu karang. Ikan kurau mampu mentolerir kadar garam (salinitas) dan beruaya di perairan estuaria dan bahkan masuk ke perairan sungai (Wati, 2012). Hasil pembedahan isi perut menunjukkan bahwa ikan kurau merupakan ikan karnivor, yang mana terdapat ikan kecil, cacing air dan udang. Kisaran suhu habitat ikan kurau ini hidup yaitu antara $23{ }^{\circ} \mathrm{C}$ sampai $30{ }^{\circ} \mathrm{C}$ dengan kisaran salinitas yang rendah antara 25 0/00 sampai 38 0/00, dan ikan kurau merupakan jenis ikan soliter dan ada juga bergerombol namun sekali-kali terjadi (Rengi et al. 2015).

Menurut Nasution (2009) nama ikan kurau dapat berbeda-beda di setiap wilayah, di Inggris ikan kurau biasa disebut giant treadfin (tassel fish) atau indian salmon. Di Indonesia ikan kurau dan ikan senangin merupakan dua jenis ikan yang berbeda species tetapi satu family (keluarga), pada umumnya kedua jenis ikan ini memiliki banyak kesamaan, yang membedakannya yaitu mulut (moncong) ikan kurau lebih panjang dari pada ikan senangin, selain itu perbedaan yang mencolok 
lainnya dapat dilihat dari corak warna, bola mata dan sisik. Ikan kurau juga mempunyai sebutan lain di beberapa daerah di Indonesia seperti: baling/kuro (Jawa), laceh (Madura), senangin (Sumatera Selatan), selangih (Sumatera bagian timur) dan tikus-tikus (Ambon). Menurut FAO (2004) ikan kurau diklasifikasikan sebagai berikut:

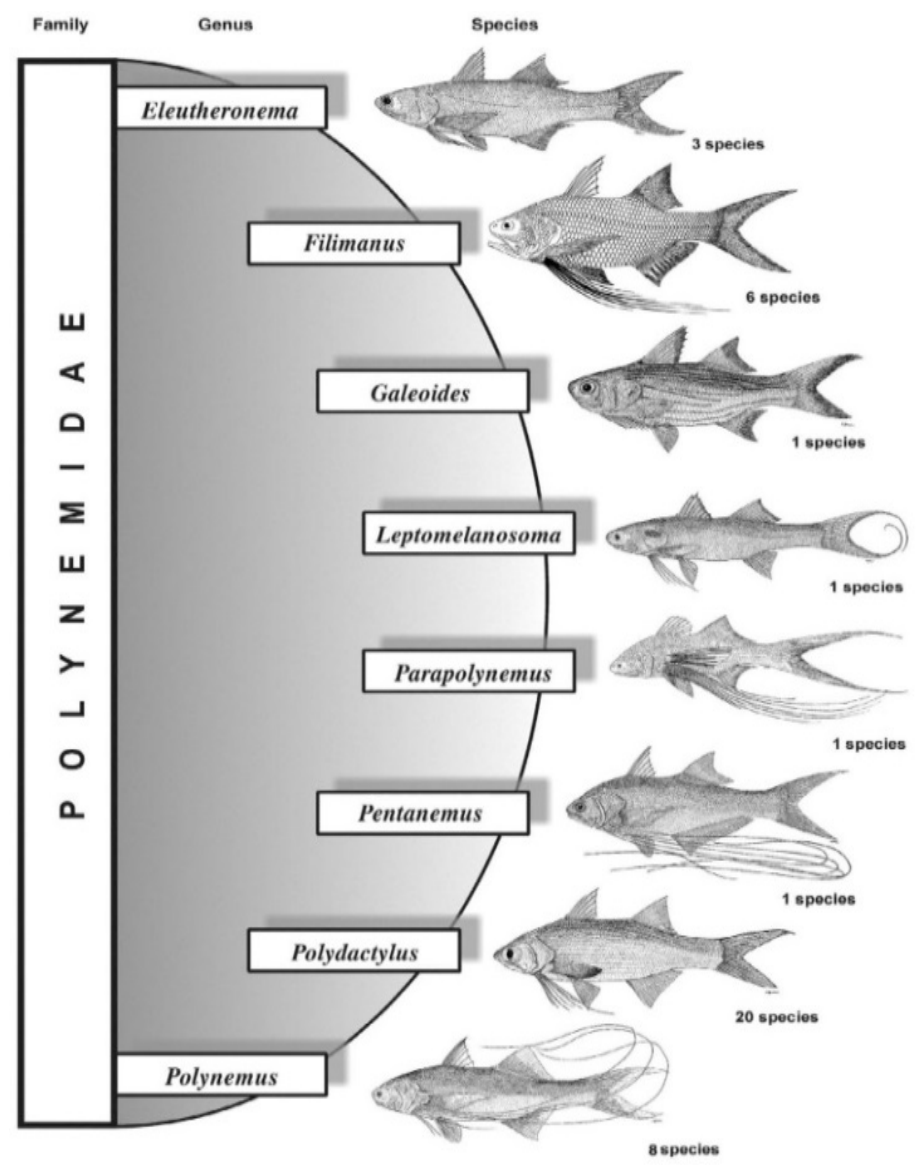

Sumber: (FAO, 2004)

\section{Gambar 4. Klasifikasi Ikan Kurau}

Hasil identifikasi ikan kurau yang tertangkap di perairan Pambang Pesisir Kabupaten Bengkalis merupakan ikan berasal dari keluarga Polynemidae dengan species Eleutheronema tetradactylum (Gambar 5). Ikan kurau merupakan jenis ikan demersal yang memiliki kemampuan renang hingga perairan payau. Ikan kurau memiliki bentuk tubuh panjang sedikit bulat (torpedo). Tubuhnya berwarna cerah kemerahan, sedikit berwarna kuning emas dan memiliki ciri khas berupa filamen pada bagian sirip dadanya, seperti helaian cambuk (jari-jari lemah). Posisi mulut dekat ujung hidung sedikit agak ke bawah (terminal) memiliki dua sirip punggung (dorsal), sirip perut terletak di belakang sirip dada (sub abdominal), sirip anus terpisah dari sirip ekor dan bentuk sirip ekor bercagak (forked) serta bola matanya berbentuk bulat sedikit cembung keluar. Ikan kurau di perairan Pambang Pesisir memiliki 4 sampai 5 helai filamen pada sirip dada sepasang (pectoralis). Panjang fileman melebihi panjang sirip ventral (sirip perut), dan memiliki ukuran yang berbeda-beda pada setiap ukuran ikan kurau. 


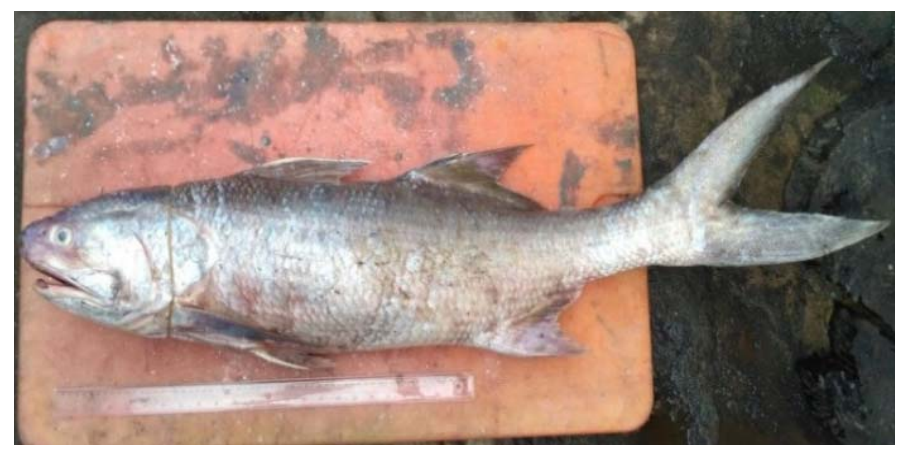

Gambar 5. Ikan Kurau (Eleutheronema tetradactylum)

\section{Frekuensi Sebaran Panjang Ikan Kurau}

Jumlah ikan kurau yang tertangkap oleh nelayan periode bulan Juli sampai September 2016 sebanyak 106 ekor, dengan ukuran panjang total (TL) tertinggi sebesar $128 \mathrm{~cm}$ dan yang terendah sebesar 27,2 cm. Ukuran Berat ikan kurau tertinggi sebesar 13,8 kg dan yang terendah sebesar 0,3 kg. Ukuran panjang cagak FL (Fork Length) ikan kurau yang banyak tertangkap pada jaring insang berada pada kisaran 31,7 cm sampai 42,7 cm pada bulan Juli dan September dengan ukuran terpanjang $123 \mathrm{~cm}$ dengan berat 12,3 kg, sedangkan pada bulan Agustus banyak tertangkap pada kisaran 61,7 cm sampai 72,7 cm dengan ukuran terpanjang $128 \mathrm{~cm}$ dengan berat 13,8 $\mathrm{kg}$ (Gambar 6). Untuk rawai dan pancing ukuran panjang cagak FL (Fork Length) ikan kurau banyak yang tertangkap pada kisaran 31,7 cm sampai 42,7 cm pada bulan Juli dan September dengan ukuran tertinggi $107 \mathrm{~cm}$ dengan berat $10 \mathrm{~kg}$, sedangkan pada bulan Agustus banyak tertangkap pada kisaran $36,7 \mathrm{~cm}$ sampai 47,7 cm dengan ukuran terpanjang $115 \mathrm{~cm}$ dengan berat 11,6 kg (Gambar 7).

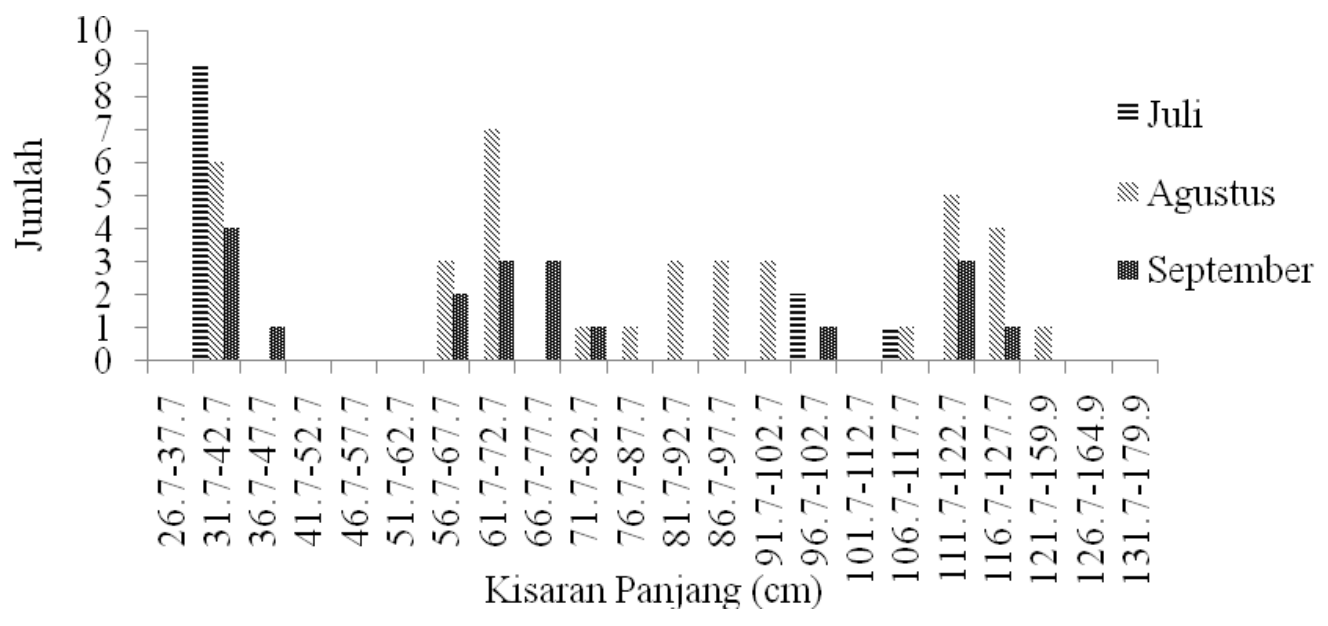

Gambar 6. Frekuensi Sebaran Panjang Ikan Kurau yang Tertangkap pada Jaring Insang 


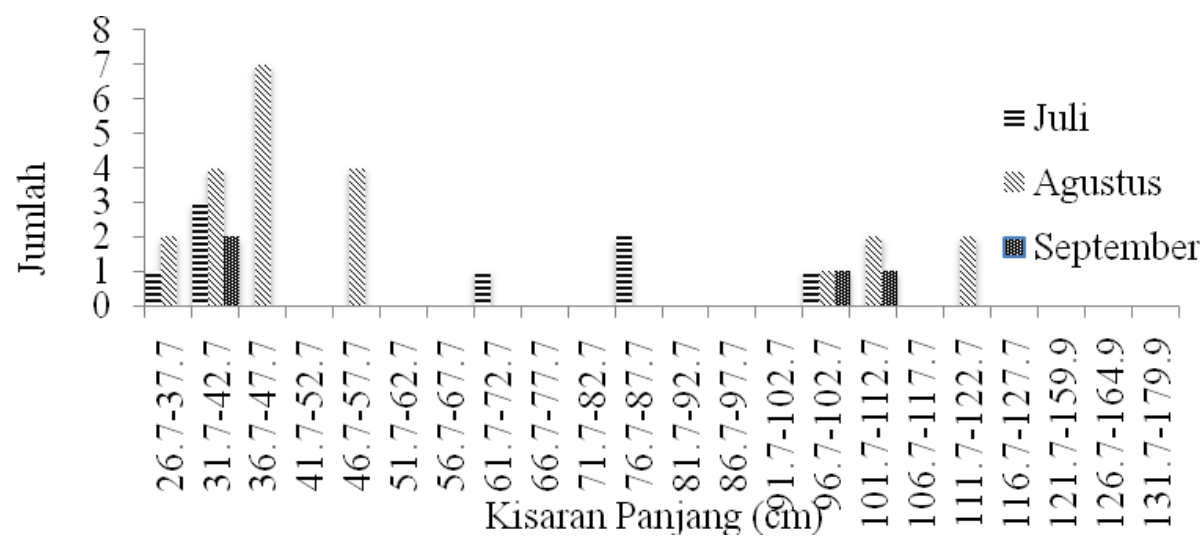

Gambar 7. Frekuensi Sebaran Panjang Ikan Kurau yang Tertangkap pada Rawai dan Pancing

\section{Ukuran Ikan Kurau Layak Tangkap}

Hasil pengukuran FL ikan kurau yang tertangkap pada jaring insang menunjukkan bahwa ikan kurau layak tangkap jantan memiliki persentase sebesar 100\% dan tidak layak tangkap tidak ada (0\%) dan untuk betina layak tangkap sebesar 72\% dan hanya 28\% yang tidak layak tangkap. Hasil persentase ikan kurau yang layak tangkap atau tidak layak tangkap pada alat tangkap jaring insang lebih jelas disajikan pada (Gambar 8).

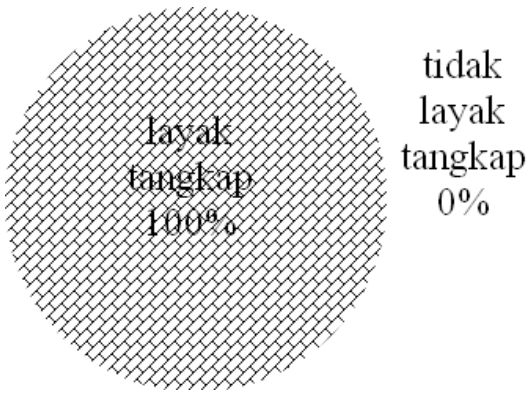

(a)

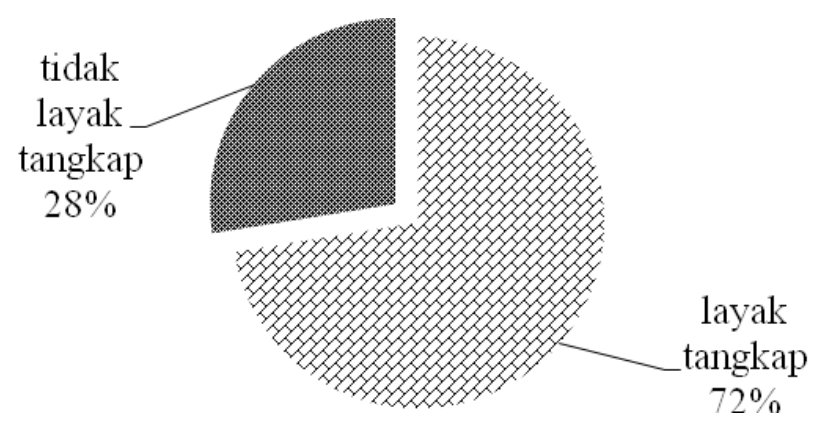

(b)

Gambar 8. Jaring Insang (a) Persentase Ikan Kurau Layak Tangkap Jantan (b) Persentase Ikan Kurau Layak Tangkap Betina

Hasil pengukuran FL ikan kurau yang tertangkap pada alat tangkap rawai dan pancing untuk jantan yang layak tangkap memiliki persentase sebesar $90 \%$ dan hanya 10\% yang tidak layak tangkap. Sedangkan untuk betina ikan kurau yang layak tangkap memiliki persentase sebesar $44 \%$ dan $56 \%$ 
yang tidak layak tangkap.Hasil persentase ikan kurau yang layak tangkap atau tidak layak tangkap pada alat tangkap rawai dan pancing lebih jelas disajikan pada (Gambar 9).

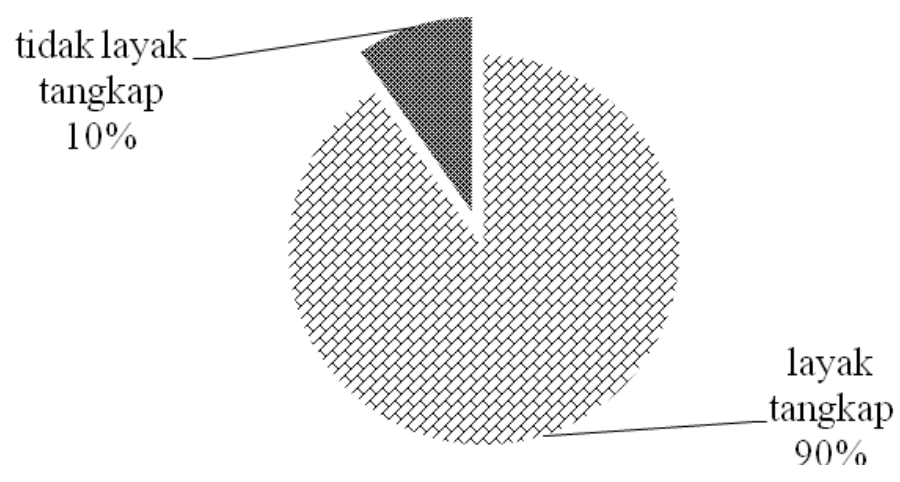

(a)

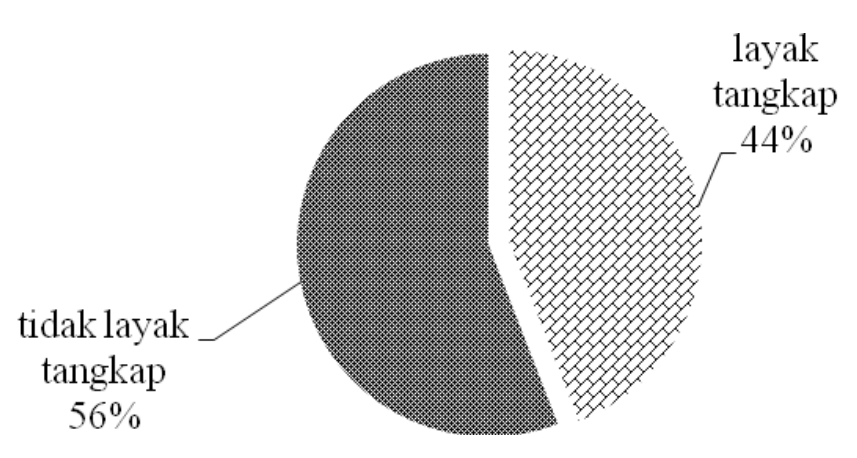

(b)

Gambar 9. Rawai dan Pancing (a) Persentase Ikan Kurau Layak Tangkap Jantan (b) Persentase Ikan Kurau Layak Tangkap Betina

\section{Hubungan Panjang dan Berat Ikan Kurau}

Hasil pengukuran dan perhitungan hubungan panjang dan berat ikan kurau didapatkan bahwa ikan ini bersifat allometrik negatif $(b<3)$ dengan persamaan $\mathrm{W}=0,9398 \times \mathrm{FL}^{1.9744}$, hal itu berarti pertambahan panjang lebih cepat berbanding pertambahan berat. Hubungan panjang dan berat ikan kurau lebih jelas dapat dilihat (Gambar 10).

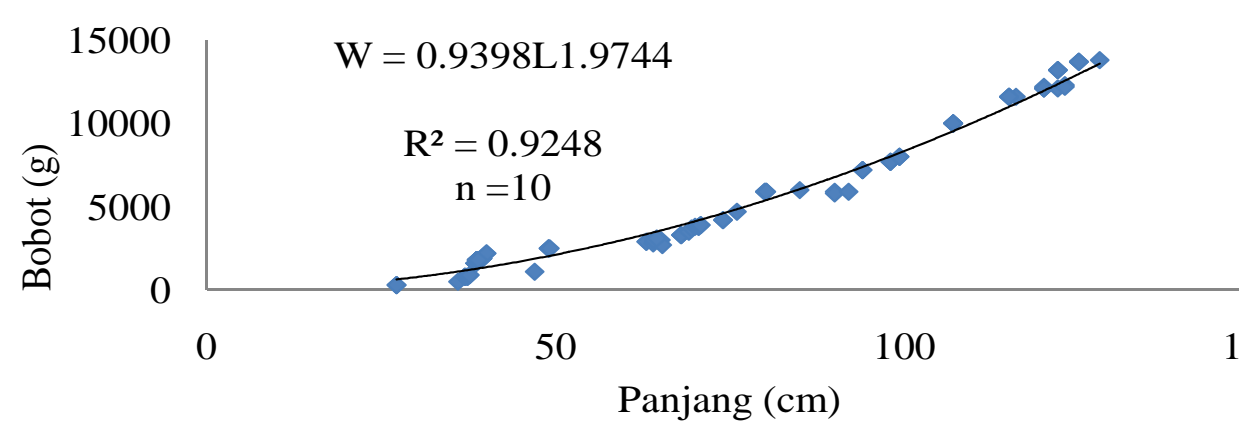

Gambar 10. Hubungan Panjang dan Berat Ikan Kurau 


\section{Struktur Ukuran}

Menurut Carpenter dan Niem (1998) ikan kurau memiliki ukuran mencapai ukuran $200 \mathrm{~cm}$, tetapi ukuran yang biasa ditemukan antara 45 sampai $50 \mathrm{~cm}$. Hasil analisis struktur ukuran ikan kurau di Pulau Bengkalis menunjukkan bahwa ikan kurau yang tertangkap oleh alat tangkap rawai relatif lebih kecil dibandingkan ikan kurau yang tertangkap oleh alat tangkap jaring insang. Alat tangkap rawai menangkap dengan rata-rata panjang 26,7-122,7 cm dan alat tangkap jaring insang menangkap dengan rata-rata panjang 31,7-159,9 cm.

Menurut Wijopriono et al. (2012) ikan kurau yang tertangkap pancing/rawai dasar mempunyai ukuran berat $0,3 \mathrm{~kg}$ sampai $6 \mathrm{~kg}$ per individu dengan panjang maksimum ditemukan sekitar $1 \mathrm{~m}$. sedangkan ikan kurau yang tertangkap jaring insang mempunyai ukuran berat minimum 2 kg dengan lingkar badan (girth) di atas $20 \mathrm{~cm}$. Perbedaan ini dapat disebabkan oleh keragaan aspek teknis dalam mengeksploitasi ikan kurau. Aspek teknis ini sangat rentan memicu konflik dan kecemburuan sosial, apalagi alat tangkap jaring kurau yang memiliki mesh size yang besar dan ukuran jaring yang begitu panjang sehingga mampu mengeksploitasi ikan kurau secara besar-besaran (Kholis et al., 2017a). Menurut Kholis et al., (2017b) karakteristik jaring insang (jaring kurau dan jaring tangsi) menggunakan webbing berbahan PA (polyamide) dan tangsi (nilon). Mesh size yang digunakan yaitu 2.5 - 7 inci dan panjang jaring berkisar 66 - $2.000 \mathrm{~m}(1,8 \mathrm{mil} / 2 \mathrm{~km})$ dengan ukuran kapal berkisar 6 $12 \mathrm{~m}$. Sedangkan rawai dan pancing menggunakan tali utama berbahan nilon 110, mata pancing bernomor 6 dan 7, dengan umpan ikan parang-parang, tenggiri, layur, udang dan lomek. Ukuran panjang kapal yang digunakan berkisar $6-8 \mathrm{~m}$.

\section{Ukuran Ikan Kurau Layak Tangkap}

Ukuran ikan kurau layak tangkap atau tidak layak tangkap cukup sulit dilakukan, dan masih sedikit sekali penelitian mengenai ukuran layak tangkap ikan kurau itu sendiri.Carpenter dan Niem (1998) menyatakan bahwa ikan kurau akan mengalami perubahan jenis kelamin menjadi betina ketika ikan kurau memiliki panjang lebih dari $40 \mathrm{~cm}$ dan berumur sekitar dua tahun. Hidup ikan kurau memiliki beberapa tahap siklus yaitu: tahap perkembangan telur, tahap perkembangan larva, ikan kurau remaja, ikan kurau berumur dua tahun (fase terjadi perubahan jenis kelamin menjadi betina), ikan kurau dewasa berumur kurang lebih empat tahun (berjenis kelamin betina) (Carpenter dan Niem, 1998).

Proses matang gonad ikan kurau terjadi secara bertahap dan diduga mengalami pemijahan secara tidak serentak (partial spawning). Jumlah fekunditas ikan kurau berkisar antara 5.468 sampai 10.256 butir dengan indeks kematangan gonad antara 7,64 \% sampai $11 \%$ (Asyari dan Herlan, 2013).

Hasil penelitian menunjukkan bahwa jaring insang lebih selektif dalam menangkap ikan kurau layak tangkap dengan persentase total 86\% layak tangkap dan 16\% tidak layak tangkap. Sedangkan rawai dan pancing menangkap ikan kurau layak tangkap dengan persentase total hanya $67 \%$ dan $33 \%$ tidak layak tangkap. Hal ini dapat disimpulkan bahwa nelayan Pulau Bengkalis rata-rata telah menangkap ikan kurau layak tangkap dengan persentase total 75,5 \%. Melihat hal ini, dalam pengelolaan ikan kurau aspek layak dan tidak layak tangkap sangat perlu diperhitungan, mengingat sifat biologis ikan kurau yang bersifat hermaphrodit protandouse, yaitu kemampuan mengubah organ kelamin seiring dengan perkembangan ukuran dan umur (Wijopriono et al., 2012).

\section{Hubungan Panjang dan Berat}

Persamaan hubungan panjang dan berat ikan kurau memiliki korelasi yang sangat erat dengan nilai koefisien korelasi (R2) mendekati angka 1 yaitu 0,9248 . Nilai $\mathrm{R}^{2}$ menunjukkan bahwa setiap penambahan berat akan diiringi dengan penambahan panjang. Pernyatakan yang sama Hartnoll (1982) menyatakan bahwa besarnya koefisien korelasi menunjukkan bahwa pertambahan panjang diikuti dengan pertambahan berat tubuh. 
Hal ini sedikit berbeda menurut Asyari dan Herlan (2013) menyatakan bahwa hubungan panjang dan berat ikan kurau di sungai Indragiri mengikuti persamaan $\mathrm{W}=0,005 \mathrm{~L}^{2.9851}$, dengan nilai $\mathrm{b}=3$, yang berarti ikan kurau mempunyai pola pertumbuhan isometrik dimana terdapat keseimbangan antara pertumbuhan panjang dengan pertumbuhan berat.

Pebedaan yang terjadi ini disebabkan oleh beberapa faktor yaitu: suhu, kualitas air, ukuran, umur, jenis ikan, jumlah ikan-ikan lain yang memanfaatkan sumber makanan yang sama, fisiologis, letak geografis dan teknik sampling serta kondisi biologis seperti perkembangan gonad Hartnoll (1982); Mulfizal et al.(2012).

Analisis hubungan panjang dan berat ikan dapat digunakan sebagai dasar menentukan biomassa untuk mengestimasi produksi perikanan (Smith, 1996). Selain itu pengukuran panjang dan berat yang dihubungkan dengan umur dapat memberikan informasi tentang komposisi stok, umur matang gonad, mortalitas, siklus hidup dan pertumbuhan (Fatioye dan Oluajo, 2005).

\section{KESIMPULAN DAN SARAN}

Pola pertumbuhan ikan kurau bersifat allometrik negatif, dengan kisaran ukuran ikan kurau yang tertangkap pada alat tangkap jaring insang dominan berada pada ukuran31,7 - 42,7 cm pada bulan Juli dan September serta kisaran 61,7 - 72,7 cm pada bulan Agustus. Sedangkan ukuran ikan kurau yang tertangkap pada rawai dan pancing dominan berada pada kisaran 31,7 - 42,7 cm pada bulan Juli dan September serta kisaran 36,7 - 47,7 cm pada bulan Agustus. Sedangkan persentase ikan kurau layak tangkap pada jaring insang yaitu untuk jantan 100\% layak tangkap dan 72\% layak tangkap untuk betina. Sedangkan ikan kurau yang layak tangkap pada rawai dan pancing untuk jantan $90 \%$ dan $44 \%$ layak tangkap untuk betina.

\section{UCAPAN TERIMA KASIH}

Penulis mengucapkan banyak terima kasih kepada Lembaga Pengelola Dana Pendidikan (LPDP) selaku lembaga yang telah membiayai penelitian inidengan surat perjanjian kontrak LPDPNomor: PRJ-4379/LPDP.3/2016.

\section{DAFTAR PUSTAKA}

Asyari \& Herlan.(2013). Beberapa Aspek Biologi Ikan Kurau (Polynemus dubius) di Estuari Sungai Indragiri, Riau. Jurnal Bawal. 5 (2), 67-72.

Blaber, S.J.M., Brewer, D.T., Milton, D.A., Merta, G.S., Efizon, D., Fry, G., \& Van Der Velde T. (1999). The Life History Of The Protandrous Tropical Shad Tenualosamacrura (Alosinae: Clupeidae): Fishery implications. Journal Estuarine Coastal and Shelf Science. (49): 689-701.

Carpenter, K.E., \&Niem, V.H. (1998).The Living Marine Resources of The Western Central Pacific. FAO Species Identification Guide for Fishery Purposes. Rome : FAO Fisheries Department.(2).

De Robert \& William, K. (2008). Weight-Length Relationship In Fisheries Studies: The Standard Allometric Model Should Be Applied With Caution. JournalTransaction Of The American Fisheries Society. (137): 707-719.

Effendie, M.I. (1997). Biologi Perikanan. Yogyakarta (ID).Yayasan Pustaka Nusantara. p.163.

Fatioye, O.O., \& Oluajo, O.A. (2005). Length-Weight Relationships Of Five Fish Species In Epe Lagoon, Nigeria. African Journal of Biotechnology. 4(7): 749-751.

Food and Agricultural Organization (FAO).(2004). Species Catalogue for Fishery Purposes No. 3:18. Rome (IT).8 pp. 
Hartnoll, R.G. (1983). Growth in The Biology of Crustacea Embriology, Morfology, and Genetic. New York (US).Academic Press.

Kholis, M.N., Wahju, R.I., \& Mustaruddin. (2017a). Seleksi Unit Teknologi Penangkapan Ikan Kurau (Eleutheronema tetradactylum) yang Unggulan dan Berkelanjutan. Jurnal Ilmu dan Teknologi Kelautan Tropis. 9(2): 521-535.

Kholis, M.N., Wahju, R.I., \& Mustaruddin.(2017b). Keragaan Aspek Teknis Unit Teknologi Penangkapan Ikan Kurau di Pambang Pesisir Kabupaten Bengkalis Provinsi Riau.Jurnal Teknologi Perikanan dan Kelautan. 8(1): 67-73.

Milton, D.A., Die, D., Tenakanae, C., \& Swales, S. (1998). Selectivity for barramundi (Latescalcarifer) In The Fly River, Papua New Guinea: Implications For Managing Gill-Net Fisheries On Protandrous Fishes. Journal Marine and Freshwater Research. (49): 499-506.

Mulfizar, A.M., Zainal, \& Irma, D. (2012).Hubungan Panjang dan Berat dan Faktor Kondisi Tiga Jenis Ikan Yang Tertangkap di Perairan Kuala Gigieng Aceh Besar Provinsi Aceh. Jurnal Depik. 1(1): 1-9.

NasutionA. (2009). Analisis Ekologi Ikan Kurau (Eleutheronema tectradactylum) pada perairan laut Bengkalis Provinsi Riau. [Thesis].FMIPA. Program Studi Ilmu KelautanUniversitas Indonesia. Depok (ID). p.69 .

Patnaik, S. (1969). A Contribution To The Fishery And Biology Of Chilka Sahal, Eleutheronema tetradactylum (Shaw). Journal Central Inland Fisheries Research. 34-61.

Poepoe, K., Bartram, P., \& Friedlander, A. (2003). The Usage of Traditional Hawaiian Knowledge in The Contemporary Management of Marine Resources. In: Haggan, N., Brignall, C., Wood, L. (eds). Putting Fishers' Knowledge to Work, Conference Proceedings August 27-30, 2001, Fisheries Centre, Universityof British Columbia, Canada. 328-339 pp.

Rengi, P., Tang, U.M., Syahza, A., \&Ikhwan, S.Y. (2015).Status, Exploration Potential and Resource Management Of Kurau (Eleutheronema Tetradactylum) Fish In Overfishing Area (Case Study In Bengkalis District, Riau Province). International Journal of Research In Earth and Environmental Sciences. 3(2): 8-12.

Sari, T.E.Y., Wisudo,S.H., Monintja,D.R,, \&Purwaka,T. (2009). Prospek Pengembangan Perikanan Tangkap Di Perairan Provinsi Riau.Buletin PSP (18): 133-141.

Smith, K.M.M. (1996). Length-Weight Relationships Of Fishes In A Diverse Tropical Freshwater Cunnunity Sabah, Malaysia. Journal of Fish Biology (49): 731- 734.

Syaifuddin. (2008). Pendugaan Potensi dan Pola Musim Penangkapan Ikan Kurau(Eleutheronema tetradactylum) di Perairan Pulau Bengkalis.. Lembaga Penelitian Universitas Riau. Pekanbaru (ID). $35 \mathrm{pp}$.

Walpole. 1995. Pengantar Statistika. Jakarta (ID). Gramedia Pustaka Utama.

Wati. (2012). Identifikasi Metode Penangkapan Ikan Kurau di Desa Teluk Pambang Kecamatan Bantan Kabupaten Bengkalis Provinsi Riau. Jurnal Online Mahasiswa. 2(1) 1-13.

Wijopriono. Nugroho,D., \&Sadhotomo, B. (2012). Tren Pemanfaatan Sumberdaya Ikan Kurau (Polinimidae) di Perairan Bengkalis Selat Malaka. Jurnal Penelitian Perikanan Indonesia. 18( 4): 205-212.

Wujdi, A., Suwarso \& Wudianto. (2013). Hubungan Panjang Bobot, Faktor Kondisi dan Struktur Ukuran Ikan Lemuru di Perairan Selat Bali. Jurnal Bawal. 4(2), 83-89. 